\title{
PLANIRANJE VODNE BEZBEDNOSTI U LOKALNIM ZAJEDNICAMA U USLOVIMA PROMENE KLIME - PRIMER ZEMALJA BLISKOG ISTOKA I SEVERNE AFRIKE
}

\author{
Slobodan Milutinović ${ }^{1}$, Radoje Laušević ${ }^{2} \quad$ UDK=351.79:551.583(1-2)(5-15)(61) \\ https://doi.org/10.18485/fb_ubur.2018.1.ch12 \\ ${ }^{1}$ Fakultet zaštite na radu, Univerzitet u Nišu, boban40@yahoo.com \\ ${ }^{2}$ Futura, Fakultet za primenjenu ekologiju, Beograd, \\ radoje.lausevic@gmail.com
}

\section{Sažetak}

Vodna bezbednost je daleko više od toga da li ima ili nema dovoljno vode, ona podrazumeva sve aspekte problema koje zovemo „imati premalo vode“, „imati previše vode“ ili „imati previše prljavu vodu“. Mnogo ljudi u urbanim sredinama danas oseća ove probleme i oni se donekle rešavaju dobrim upravljanjem vodom u gradovima. Međutim, vodna bezbednost je znatno više od dobrog upravljanja: ona se bavi smanjenjem rizika povezanih sa vodom, kao što su poplave i suše, konfliktima koji nastaju zbog zajedničkog korišćenja vode i smanjenjem tenzija između različitih učesnika koji pretenduju na korišćenje ograničenih resursa.

Svetski ekonomski forum je 2009. godine bezbednost vode proglasio jednim od najvećih globalnih rizika, naglašavajući da je ,,vodna bezbednost ona tanka nit koja povezuje mreže hrane, energije, klime, ekonomskog razvoja i izazova ljudske bezbednosti, koja će u sledećim decenijama predstavljati izazov za globalnu ekonomiju“. Prema definiciji Globalnog partnerstva za vodu ,vodna bezbednost na bilo kojem nivou, od domaćinstva do globalnog nivoa, označava da je svakom pojedincu dostupno dovoljno čiste vode po pristupačnoj ceni, kako bi njegov život bio čist, zdrav i produktivan, dok se u isto vreme osigurava da životna sredina bude zaštićena i unapređena“. Vodna bezbednost uključuje održivo korišćenje i zaštitu vodnih resursa, zaštitu od rizika koji su u vezi sa vodom (poplava i suša), održivi razvoj vodnih resursa i osiguravanje ekoloških funkcija i pristupa funkcijama koje voda ima u životnoj sredini.

Pitanja vodne bezbednosti javljaju se na dva međusobno povezana nivoa: lokalnom (nacionalnom) i regionalnom (međunarodnom). Na lokalnom nivou osiguravanje dostupnosti resursâ pojavljuje se kao najveća teškoća. Na regionalnom nivou najveći problemi vezani su za potencijalne međunarodne konflikte i tenzije koje nastaju kao rezultat tradicionalnog pristupa nacionalne bezbednosti zasnovane na suverenosti nad vodnim resursima. U oba slučaja je dobro upravljanje vodom ključno za ostvarivanje vodne bezbednosti. Međutim, danas se sve više uviđa da se problemi vezani za vodnu bezbednost mogu uspešno rešavati i na nivou lokalnih zajednica, pre svega u domenu zaštite od rizika povezanih sa promenama klime, lokalne dostupnosti vodnih resursa i zaštite voda. 
Ovaj rad se bavi pokaznim i razvojnim projektom "WaterSUM - Sustainable Use of Transboundary Water Resources and Water Security Management", čiji je cilj bio unapređenje vodne bezbednosti na lokalnom nivou, prevashodno u gradovima dve države u regionu Bliskog istoka i severne Afrike - Jordana i Tunisa. Projekat finansiran od strane Švedske agencije za međunarodnu razvojnu saradnju (SIDA) sproveo je u periodu od 2014. do 2017. godine Regionalni centar za životnu sredinu (Regional Environmental Center - REC) u Jordanu, Tunisu, Egiptu i Maroku, gde se upravljanje vodama i bezbednost mogu smatrati vrhunskim prioritetima. Opšti cilj projekta je bio promovisanje i unapređenje održivog upravljanja vodnim resursima i promocija sveobuhvatnog i integrisanog pristupa vodnoj bezbednosti i ekosistemskim uslugama u cilju održivog razvoja u državama regiona Bliskog istoka i centralne Afrike (MENA), kako bi se na taj način pomoglo zaustavljanju spirale siromaštva, gubitka biodiverziteta i degradacije životne sredine.

Akciono planiranje vodne bezbednosti na lokalnom nivou imalo je ključno mesto u drugoj komponenti projekta WaterSUM pod nazivom "Water and Security" (WaSe). Zašto baš vodna bezbednost na nivou lokalnih zajednica? Nebezbednost vode na lokalnom nivou, bilo da je reč o nedostatku vode ili o njenom lošem kvalitetu, može dovesti do političke nestabilnosti i sukoba, koji se često mogu pogoršati pokušajima profitiranja nekontrolisanom prodajom pitke vode od strane privatnih kompanija. Pretnje kojima su izloženi vodni resursi i ekosistemi mogu dodatno pogoršati ovo stanje. Sprovođenje bilo koje politike u oblasti smanjenja siromaštva, održivog razvoja i zaštite biodiverziteta nemoguće je bez aktivnog učešća i vođstva od strane lokalnih vlasti u saradnji sa njihovim strateškim partnerima (kao što su nacionalne vlasti, civilni sektor i poslovna zajednica). Stoga je upravljanje vodama na lokalnom nivou osnovni element dobrog upravljanja vodama.

U okviru projekta WaterSUM razvijeni su inovativni pristupi i alati, koji su testirani kroz pilot-projekte na osam različitih urbanih i periurbanih lokacija u Jordanu i Tunisu (Džeraš, Karak, Adžlun i Salt u Jordanu, te Matmata, Nefza, Bir Mčerga i Sidi Ali Ben Oun u Tunisu). Lokalni proces akcionog planiranja vodne bezbednosti dizajniran je tako da obuhvata dva međusobno povezana koraka: procenu trenutnog stanja vodne bezbednosti i razvoj akcionog plana ili plana upravljanja. Metodologija za planiranje, detaljno opisana u priručniku za planiranje (http://documents.rec.org/publications/LWSAP_Manual_April2016.pdf), bazirana je na elementima preuzetim iz dve metodologije za procenu: Water Security Status Indicators (WSSI); i Canadian Water Sustainability Index (CWSI). Autori su razvili originalnu metodologiju koja obuhvata sedam međusobno povezanih aktivnosti, uključujući analizu zainteresovanih strana, procenu javnog mnjenja, lokalnu procenu bezbednosti vode i analizu problema i prioriteta. Svaka od sedam aktivnosti sadrži dva ili više koraka, što čini ukupno 20 koraka u procesu planiranja.

Lokalni procesi akcionog planiranja vodne bezbednosti, bazirani na metodologiji opisanoj u priručniku, započeti su u osam odabranih lokalnih zajednica početkom 2016. U ovom trenutku proces planiranja je u završnoj fazi i najveći broj lokalnih zajednica sačinio je nacrte akcionih planova. Iako je još rano za konačnu evaluaciju pilot-procesa, neka zapažanja se nameću.

Kao prvo, nema dileme da se planiranje vodne bezbednosti na lokalnom nivou, bazirano na metodologiji koja je ponuđena, može smatrati neophodnim procesom za lokalne zajednice u regionu, posebno za one koje su bile uključene u projekat. U ovome momentu neophodnost korišćenja metodologije za planiranje akcija u oblasti vodne bezbednosti na lokalnom nivou 
ne dovodi se u pitanje, iako se može raspravljati o detaljima metodološkog pristupa, uključujući i njegovo poboljšanje.

Kada se govori o samom procesu planiranja, postoji generalni problem nedostatka pouzdanih podataka. Sâm proces planiranja se pokazao ekstremno dugotrajnim zbog manjka nepobitnih podataka i veština za njihovo prikupljanje i analizu, što se pre svega odnosi na analizu zatečenog stanja. Zbog toga je u nekim lokalnim zajednicama dolazilo do kašnjenja, a u pojedinim slučajevima rezultati planiranja nisu bili zadovoljavajući.

Praćenje razvoja na lokalnom nivou i monitoring razvojnog procesa sve više se smatra osnovom za uspeh bilo koje razvojne inicijative. Međutim, i ovde najveći problem leži u nedostatku pouzdanih i relevantnih podataka i, još više, sistematskog upravljanja, obrade i obnavljanja ovih podataka.

Uspešnost planiranja na lokalnom nivou bila je u direktnoj korelaciji sa administrativnim nivoom i unutrašnjim kapacitetima lokalne vlasti da uključi zainteresovane strane u proces planiranja. Lokalne vlasti u regionu se razlikuju i imaju različite nivoe znanja i ljudskih resursa. Međutim, uloga facilitatora pokazala se kao veoma važna u svakoj lokalnoj zajednici, jer su oni pokretali proces i osiguravali da on bude uspešan i da se rokovi poštuju.

Proces planiranja se zasnivao na klasičnoj metodologiji participativnog planiranja. No, interesovanje javnosti za učešće u planiranju vodne bezbednosti još i sada je malo, uprkos skorašnjim povoljnim iskustvima.

Zajedničko razumevanje potrebe za strateškim pristupom u planiranju vodne bezbednosti i sama metodologija koja se koristila tek su u manjoj meri predstavljali administrativni problem, pre svega u ranoj fazi procesa planiranja. Sa druge strane, najveći izazov je bio da se proces dizajnira tako da lokalnoj zajednici bude vidljiv i atraktivan, a posebno da se održi motivacija za rad i ,tenzije“ unutar radnih grupa tokom dugotrajnog procesa, kakav je po prirodi proces formulisanja strategije i njene implementacije.

Dakle, u savremenom svetu vodna bezbednost sve više postaje jedan od najznačajnijih aspekata urbane bezbednosti. U ovom radu prikazan je konceptualni okvir vodne bezbednosti, sa posebnim osvrtom na vodnu bezbednost u lokalnim zajednicama. Osim toga, prikazan je primer metodologije za planiranje vodne bezbednosti u lokalnim zajednicama regiona Bliskog istoka i severne Afrike, urađenih u Jordanu i Tunisu u okviru projekta „WaterSUM - Sustainable Use of Transboundary Water Resources and Water Security Management" Regionalnog centra za životnu sredinu (Regional Environmental Center - REC) iz Budimpešte, finansiranog od strane Švedske agencije za međunarodnu razvojnu saradnju (SIDA). Planiranje vodne bezbednosti na lokalnom nivou, bazirano na metodologiji koja je ponuđena, može smatrati neophodnim procesom za lokalne zajednice u regionu, posebno za one koje su bile uključene u projekat.

Ključne reči: vodna bezbednost, akciono planiranje, lokalne zajednice, MENA 


\section{Uvod}

Vodna bezbednost je osetno više od toga da li ima ili nema dovoljno vode, ona podrazumeva sve aspekte problema koje zovemo ,imati premalo vode“, „imati previše vode“ ili „imati previše prljavu vodu“. Mnogi ljudi u urbanim sredinama danas osećaju ove probleme i oni se donekle rešavaju dobrim upravljanjem vodom u gradovima. Međutim, vodna bezbednost je znatno više od dobrog upravljanja: ona se bavi smanjenjem rizika povezanih sa vodom, kao što su poplave i suše, konfliktima koji nastaju zbog zajedničkog korišćenja vode i smanjenjem tenzija između različitih učesnika koji pretenduju na korišćenje ograničenih resursa.

Zašto se ljudi osećaju nebezbednim u vezi sa vodom? Postoji više razloga:

- nepostojanje, ili nedovoljna politička volja da se unapredi snabdevanje vodom i upravljanje vodnim resursima;

- nedovoljna ulaganja u sisteme vodosnabdevanja i sisteme za upravljanje vodama;

- nizak nivo znanja i veština za upravljanje sistemima vodosnabdevanja i upravljanja vodama;

- nedovoljan ljudski kapital za upravljanje sistemima vodosnabdevanja i upravljanja vodama;

- isključivanje određenih društvenih grupa, zbog njihove nemogućnosti da plate, političke pripadnosti, invaliditeta, rase, kaste, pola, starosti ili socijalnog statusa.

Imajući navedeno u vidu, da bi se poboljšao ukupni nivo vodne bezbednosti, neophodno je unaprediti dostupnost vode (kroz kontrolisano snabdevanje kvalitetnom i zdravstveno bezbednom vodom) i pristup vodi (kroz ostvarljivo pravo na vodu za čitav niz zainteresovanih strana), kao i odgovarajućim mehanizmima izbegavati ili rešavati konflikte u korišćenju vode, koji se mogu pojaviti kao rezultat konkurencije u zahtevima za vodom.

U ovom radu su prikazani neki od rezultata razvojnog projekta "WaterSUM - Sustainable Use of Transboundary Water Resources and Water Security Management", čiji je cilj bio unapređenje vodne bezbednosti na lokalnom nivou, prevashodno u gradovima dve države u regionu Bliskog istoka i severne Afrike - Jordana i Tunisa. Projekat finansiran od strane Švedske agencije za međunarodnu razvojnu saradnju (SIDA) sproveo je u periodu od 2014. do 2017. godine Regionalni centar za životnu sredinu (Regional Environmental Center - REC) u Jordanu, Tunisu, Egiptu i Maroku, gde se upravljanje vodama i bezbednost mogu smatrati vrhunskim prioritetima. Opšti cilj projekta je bio promovisanje i unapređenje održivog upravljanja vodnim resursima i promocija sveobuhvatnog i integrisanog pristupa vodnoj bezbednosti i ekosistemskim uslugama u cilju održivog razvoja u državama regiona Bliskog istoka i severne Afrike (MENA), kako bi se na taj način pomoglo zaustavljanju spirale siromaštva, gubitka biodiverziteta i degradacije životne sredine. 


\section{Koncept vodne bezbednosti}

Prema definiciji Globalnog partnerstva za vodu (Global Water Partnership - GWP), ,... vodna bezbednost na bilo kojem nivou, od domaćinstva do globalnog nivoa, označava da je svakom pojedincu dostupno dovoljno čiste vode po pristupačnoj ceni, kako bi njegov život bio čist, zdrav i produktivan, dok se u isto vreme osigurava da životna sredina bude zaštićena i unapređena“ (1). Vodna bezbednost uključuje održivo korišćenje i zaštitu vodnih resursa, zaštitu od rizika koji su u vezi sa vodom (poplava i suša), održivi razvoj vodnih resursa i osiguravanje ekoloških funkcija i pristupa funkcijama koje voda ima u životnoj sredini. ${ }^{1}$

Svetski ekonomski forum je 2009. godine bezbednost vode proglasio jednim od najvećih globalnih rizika, naglašavajući da je ,vodna bezbednost ona tanka nit koja povezuje mreže hrane, energije, klime, ekonomskog razvoja i izazova ljudske bezbednosti, koja će u sledećim decenijama predstavljati izazov za globalnu ekonomiju“. Međutim, naučna javnost i stručnjaci koji se bave vodom počeli su da koriste termin vodne bezbednosti mnogo ranije. Tokom II Svetskog foruma voda (II World Water Forum), koji je održan 2000. godine, koncept vodne bezbednosti promovisan je u okviru dve najvažnije deklaracije: Svetski savet za vode (World Water Council - WWC) predstavio je svoju viziju u dokumentu "A Water Secure World - Vision for Water, Life, and the Environment" (2), dok je Globalno partnerstvo za vodu objavilo publikaciju "Towards Water Security: A Framework for Action" (1).

Saglasno ovim dokumentima, vodna bezbednost obuhvata održivo korišćenje i zaštitu resursâ i sistemâ za snabdevanje vodom, zaštitu od rizika koji su povezani sa vodom (pre svih, poplava i suša), održivi razvoj vodnih resursa i osiguravanje (pristupa) funkcijama i uslugama koje voda ima ili pruža stanovništvu i životnoj sredini. U Ministarskoj deklaraciji II Svetskog foruma voda, pod nazivom „Vodna bezbednost u 21. veku“, navodi se sedam osnovnih izazova koji stoje na putu ostvarivanja vodne bezbednosti:

1) zadovoljenje osnovnih potreba za vodom;

2) osiguravanje dovoljnih zaliha hrane;

3) zaštita ekosistema;

4) raspodela vodnih resursa;

5) upravljanje rizicima;

6) vrednovanje vode po stvarnoj vrednosti i

7) pametno upravljanje vodom.

1 U međuvremenu su se pojavile i nove definicije vodne bezbednosti: Grey i Sadoff (2007) definišu vodnu bezbednost kao dostupnost vode prihvatljivog kvaliteta i količine kako bi se očuvali zdravlje stanovništva, sredstva za život, ekosistemi i proizvodnja, udruženu sa prihvatljivim nivoom rizika vezanih za vodu u pogledu ljudi, životne sredine i proizvodnje (3). Agencija Ujedinjenih nacija za vodu (UN Water Agency) definiše bezbednost vode kao kapacitet stanovništva da osigura održiv pristup adekvatnim količinama prihvatljive vode za održavanje uslovâ života, ljudskog blagostanja i društveno-ekonomskog razvoja, osiguravanje zaštite od zagađenja i katastrofa povezanih sa vodom, kao i očuvanje ekosistema u okruženju koje karakterišu mir i politička stabilnost (4). 
Dijagnostikovanje vodne bezbednosti uključuje programe kojima se procenjuju stanje i razvoj ovih sedam kategorija. Ovakve analize trebalo bi da identifikuju stepen ranjivosti korisnika, sektora ili geografskih područja te da otkriju uzročno-posledične veze između pokretačkih snaga prouzrokovanih ljudskim aktivnostima ili onih na koje ovakve aktivnosti nemaju uticaj i posledica vezanih za vodu. Informacije koje pružaju ovakve analize preduslov su za bilo kakve aktivnosti koje vode integraciji ekonomskih pokazatelja, društvene jednakosti i održivosti životne sredine u oblasti upravljanja vodama.

Postoje dva pristupa za rešavanje problema vodne bezbednosti (5). Jedan je razvojni pristup, kojim se nastoji unaprediti vodna bezbednost tokom vremena. Ovaj pristup se obično zasniva na ishodima, oličenim kroz ciljeve i očekivane rezultate, do kojih se dolazi kombinacijom politika, reformi i investicionih projekata. Drugi je pristup zasnovan na riziku, koji ima cilj da upravlja rizicima i smanji osetljivost na šokove izazvane varijabilnošću klime i katastrofama povezanih sa vodom.

Očigledno je da za rešavanje pitanja voda - koja su u velikoj meri vezana za raspodelu oskudnih vodnih resursa i obezbeđivanje neophodnih količina vode, a koja se ispoljavaju na različitim nivoima i zavise od različitih sektora - treba koristiti integrisane i holističke pristupe. Rešenja za ove probleme u velikoj meri se oslanjaju na pametnu integraciju i koordinaciju. Danas se integrisano upravljanje vodnim resursima (IWRM) smatra zlatnim standardom i pravom kombinacijom za rešavanje problema voda.

Integrisano upravljanje vodnim resursima ima svrhu da se međusobno usaglase različiti fizički sistemi, kao i da se fizički sistemi integrišu sa društvenim sistemima, uključujući upravljanje, kako bi se na transparentan i inkluzivan način uskladili procesi odlučivanja na različitim nivoima i u različitim prostornim celinama. Pretpostavlja se da će upravljanje doprineti razvoju i sprovođenju pravičnih, efikasnih i održivih rešenja za alokaciju hidroobjekata i obezbeđivanje vode, kao i za rešavanje problema koordinacije. Dobro upravljanje (good governance) trebalo bi da podrazumeva anticipaciju i pravovremeno reagovanje na zahteve za vodom, rešenja zasnovana na konsenzusu, društvenu uključenost, efektivnost i efikasnost, učešće, transparentnost, odgovornost i vladavinu prava.

Pitanja vodne bezbednosti figurišu na dva međusobno povezana nivoa: lokalnom (nacionalnom) i regionalnom (međunarodnom). Na lokalnom nivou osiguravanje dostupnosti resursâ javlja se kao najveći problem. Na regionalnom nivou najveći problemi vezani su za potencijalne međunarodne konflikte i tenzije koje nastaju kao rezultat tradicionalnog pristupa nacionalne bezbednosti, zasnovanog na suverenosti nad vodnim resursima. U oba slučaja je dobro upravljanje vodom ključno za ostvarivanje vodne bezbednosti. Međutim, danas se sve više uviđa da se problemi vezani za vodnu bezbednost mogu uspešno rešavati i na nivou lokalnih zajednica, pre svega u domenu zaštite od rizika povezanih sa promenama klime, lokalne dostupnosti vodnih resursa i zaštite voda. 


\subsection{Dimenzije vodne bezbednosti}

Bezbednost voda ima tri ključne dimenzije - socijalnu jednakost, održivost životne sredine i ekonomsku efikasnost, odnosno žargonski rečeno: ljude, planetu i profit.

Ekonomska dimenzija vodne bezbednosti uključuje:

- $\quad$ povećanje produktivnosti i uštede vode u svim sektorima koji je koriste; i

- raspodelu ekonomskih, društvenih i ekoloških koristi kroz upravljanje prekograničnim rekama, jezerima i podzemnim vodama.

Društvena dimenzija vodne bezbednosti uključuje:

- obezbeđivanje ravnopravnog pristupa vodnim resursima za sve kroz odgovarajuće praktične politike i zakonske okvire na svim nivoima; i

- jačanje otpornosti zajednica na ekstremne događaje koji su u vezi sa vodom.

Dimenzija održivosti životne sredine obuhvata:

- upravljanje održivošću vodnih resursa kao deo zelene ekonomije; i

- restauraciju ekosistemskih usluga u vodnim slivovima u cilju unapređivanja ,zdravlja“ reka.

\subsection{Pretnje vodnoj bezbednosti}

Danas se zajednice u skoro svim delovima sveta suočavaju sa višestrukim pretnjama kada je u pitanju voda. U svom dokumentu iz 2012. godine WaterAid navodi devet grupa uticaja koji danas predstavljaju osnovne pretnje za vodnu bezbednost (6):

- nedostatak političke volje i nedovoljni institucionalni kapaciteti za upravljanje vodnim resursima i uslugama vodosnabdevanja;

- društvena i politička isključenost (zbog nemogućnosti plaćanja, političke pripadnosti, invaliditeta, rase, kaste, pola, starosti ili socijalnog statusa);

- siromaštvo;

- nedovoljna otpornost zajednica da se nose sa poremećajima u vodosnabdevanju;

- loši higijenski i sanitarni uslovi;

- ubrzan ukupni rast stanovništva i urbanizacije;

- klimatske promene i varijabilnost klime;

- kompleksni hidrogeološki uslovi i izazovni tereni;

- loše pozicioniranje, projektovanje i izgradnja postrojenja za vodosnabdevanje.

\section{Stanje vodne bezbednosti u zemljama Bliskog istoka i severne Afrike}

$\mathrm{Na}$ osnovu sprovedene analize u 8 zemalja regiona MENA (the Middle East and Northern Africa) - regiona Bliskog istoka i severne Afrike (Maroko, Alžir, Tunis, Libija, Egipat, Sirija, Liban i Jordan) (7), može se zaključiti da se danas ceo region 
MENA suočava sa velikim razvojnim izazovima, uključujući izazove koji su vezani za narušavanje stanja životne sredine. Region MENA je najsušnija oblast u svetu i ova činjenica sve više utiče na ekonomski i društveni razvoj u zemljama regiona. Oko 6,3\% ukupnog svetskog stanovništva koje živi u zemljama ovog regiona trenutno koristi samo $0,7 \%$ raspoloživih vodnih resursa u svetu. Pored toga, region MENA se suočava i sa drugim velikim razvojnim izazovima. To uključuje rapidno rastuću mladu populaciju, visoke stope nezaposlenosti i visoku izloženost promenama cena na tržištu nafte i klimatskim promenama. Region se takođe suočava sa brojnim političkim i bezbednosnim izazovima, uključujući i ekstremizam.

Lokalne vlasti u gotovo svim državama područja MENA karakteriše nedostatak resursâ i finansijske moći. One često imaju previše zaposlenih, ali bez odgovarajuće tehničke stručnosti. Način odlučivanja je hijerarhijski i veoma često netransparentan. Lokalno planiranje razvoja ili nije zastupljeno, ili pati od velikog broja problema.

Vodni resursi se eksploatišu preko granica održivosti i može se očekivati da će se u budućnosti ovakav trend pogoršati. Trenutno ukupne potrebe za vodom premašuju prirodne rezerve vode za blizu 20\%. Manjak dostupne vode, koji se danas procenjuje na 6,6 milijardi kubnih metara u regionu, može narasti desetostruko, na čak 65,5 milijardi kubika, što će naročito ugroziti Egipat, Maroko i Siriju (7).

Od analiziranih zemalja Jordan, Maroko i Sirija zavise uglavnom od podzemnih voda. Razlike u potražnji i raspoloživim kapacitetima danas se u najvećoj meri pokrivaju neodrživim crpljenjem podzemnih rezervoara vode i delimično određenim količinama vode dobijenim desalinizacijom morske vode. Rezultat toga je vrtoglavo snižavanje nivoa vode u podzemnim izdanima, ali i salinizacija nekih podzemnih rezervoara zbog intruzije morske vode, pre svega u priobalnim područjima severnoafričkih država.

Osnovne slabosti sistema za vodosnabdevanje u regionu Bliskog istoka i severne Afrike uključuju, između ostalog (7):

- Vodovodne mreže su stare, sa nedovoljnim prečnicima cevi i zahteva ozbiljnu dogradnju, rehabilitaciju i mnogo bolje održavanje. Ogromna količina vode ide na gubitke i ne donosi prihod.

- Kanalizaciona infrastruktura je takođe stara i zahteva bolje održavanje.

- Voda se neefikasno alocira na sektore, pri čemu ogromne količine vode idu za navodnjavanje u poljoprivredi.

- Cene vode nisu tržišne i ne garantuju održavanje sistema.

- Nedostaju ili su nedovoljno zastupljeni državni programi i subvencije za efikasno korišćenje vode, kojima bi se povećale uštede vode;

- Struktura proizvodnje u poljoprivredi neodgovarajuća je sa aspekta ušteda vode, tako da se gaje poljoprivredne kulture koje zahtevaju velike količine vode i navodnjavanje.

- Političke nestabilnosti u regionu utiču da se problemi snabdevanja vodom dodatno usložnjavaju. 
Rizici klimatskih promena mogu pogoršati ovu situaciju do tačke kada se javljaju sukobi u društvu zbog nedostatka ili otežanog pristupa vodi. Više ili manje, sve analizirane zemlje su izložene sličnim slabostima, koje mogu pogoršati njihovu ranjivost na klimatske promene. One prekomerno zavise od sektora koji su osetljivi na nedostatak vode, kao što su poljoprivreda, ekoturizam, akvakultura itd.

Ekološka baza je već ugrožena, naročito zagađenjem vode, degradacijom zemljišta, desertifikacijom i gubitkom biodiverziteta. Uz to, tehnološki uslovi, kao i finansijski i ljudski resursi, relativno su ograničeni za unapređenje otpornosti sektora voda prema klimatskim promenama (7). Uočavajući ove buduće izazove, većina zemalja MENA-e identifikovala je niz potencijalnih akcija koje bi se mogle preduzeti da bi se smanjila ranjivost na klimatske promene, posebno u sektorima voda i poljoprivrede.

Učešće zainteresovanih strana u pitanjima koja se tiču voda skromno je u planiranju i neadekvatno u sprovođenju planova (7). Iako u nekim od analiziranih zemalja postoji tradicija poveravanja upravljanja vodnim resursima na nivou lokalnih zajednica Udruženjima korisnika (Water User Associations - WUA), nalik balkanskim vodnim zadrugama, učešće u upravljanju vodama i donošenju odluka nije efikasno i, u nekim zemljama, ostaje bez odgovarajućeg zakonodavnog okvira.

Imajući sve navedeno u vidu, izvršena je i kvantitativna analiza za sve posmatrane zemlje (osim Libije i Sirije, za koje nije bilo dovoljno podataka), kojom su one ocenjene su u odnosu na performanse vezane za sigurnost vode (7). Zemlje su rangirane uz upotrebu metoda analitičkih hijerarhijskih procesa kao matematičkog aparata. Evaluacija je zasnovana na skupu međunarodno priznatih indikatora (korišćenih kao kriterijumi u višekriterijumskoj analizi), grupisanih u tri kontekstualne grupe: pokazatelji fizičkog stresa vodnih resursa; fizički, socijalni i ekološki pokazatelji nedostatka vode; i pokazatelji upravljanja. Svaka kontekstualna grupa obuhvatila je skup nezavisnih indikatora, kako je prikazano na Slici 1. Analiza je izvršena uz pretpostavku kako veći ukupni koeficijent za određenu državu znači da se ona suočava sa većom ozbiljnošću problema vodne bezbednosti.

Analiza je pokazala da je vodna bezbednost najugroženija u Jordanu, Tunisu i Maroku (Slika 2). Ugroženost Jordana (ukupan skor 81,75 od mogućih 100) može se pripisati fizičkom stresu, odnosno opštem nedostatku vodnih resursa. Tunis na drugome mestu (ukupno 76,68) i Maroko na trećem (ukupno 69,71) posebno su izloženi fizičkim, socijalnim i ekološkim pokazateljima nedostatka vode. Sve tri zemlje pokazuju viši učinak u kontekstu performansi upravljanja od ostalih rangiranih, što ukazuje na njihovu relativnu političku stabilnost, odgovornost, kvalitet pravne osnove i efikasnost. Druge zemlje su ocenjene sledećim skorovima: Alžir - 62,58; Egipat - 58,62; i Liban - 55,78. 


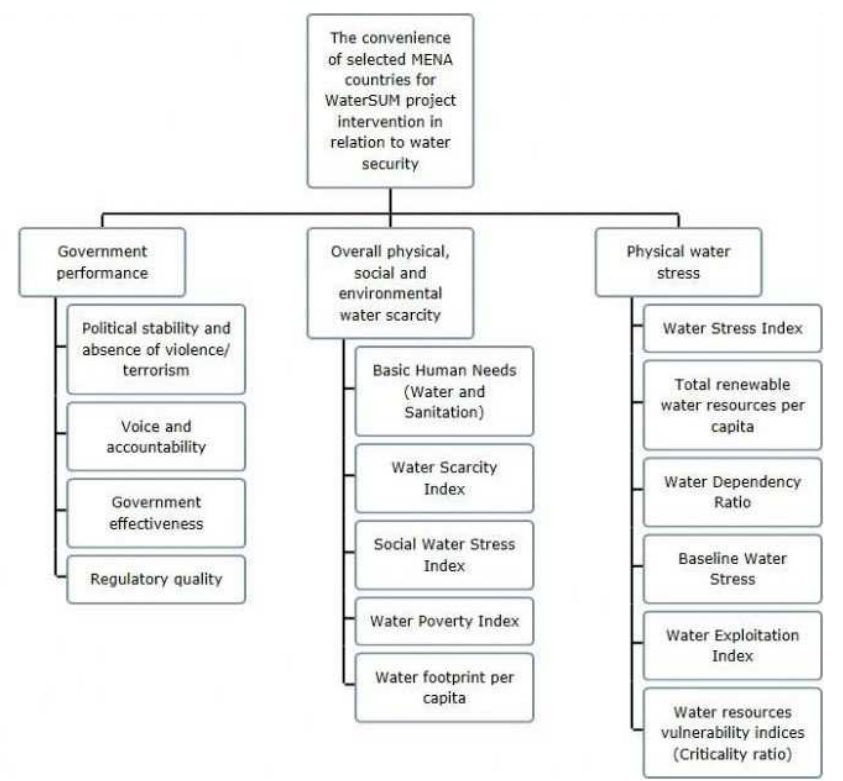

Slika 1. Blok-shema hijerarhije indikatora za analizu performansi vezanih za vodnu bezbednost u odabranim zemljama regiona MENA (7)

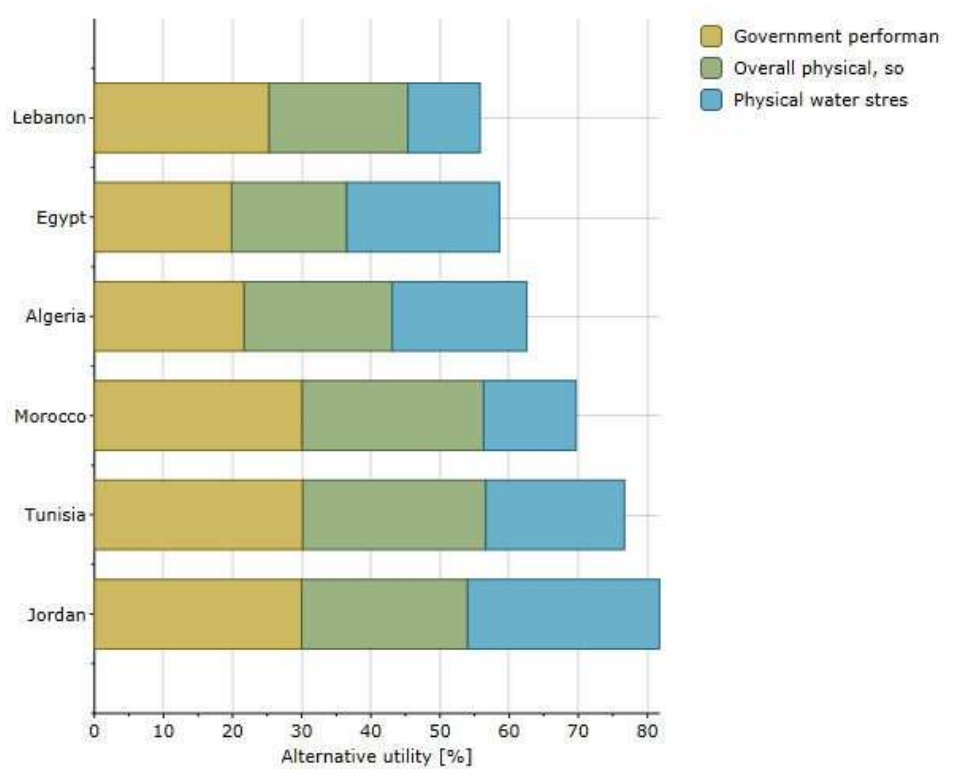

Slika 2. Rezultati rangiranja odabranih zemalja Bliskog istoka i severne Afrike u pogledu bezbednosti vode (7) 


\section{Akciono planiranje vodne bezbednosti na lokalnom nivou u Jordanu i Tunisu}

Akciono planiranje vodne bezbednosti na lokalnom nivou imalo je ključno mesto u drugoj komponenti projekta WaterSUM, pod nazivom "Water and Security" (WaSe). U ovom projektu, saglasno definiciji Ujedinjenih nacija iz 2013. godine (4), vodna bezbednost je konceptualizovana kao ,kapacitet stanovništva da osigura održivi pristup adekvatnim količinama prihvatljive vode za održavanje uslovâ života, ljudskog blagostanja i društveno-ekonomskog razvoja, osiguravanje zaštite od zagađenja i katastrofa povezanih sa vodom, kao i očuvanje ekosistema u okruženju koji karakteriše mir i politička stabilnost".

Zašto baš vodna bezbednost na nivou lokalnih zajednica? Nebezbednost vode na lokalnom nivou, bilo da je reč o nedostatku vode ili o njenom lošem kvalitetu, može dovesti do političke nestabilnosti i sukoba, koji se često pogoršavaju pokušajima profitiranja nekontrolisanom prodajom pitke vode od strane privatnih kompanija. Pretnje kojima su izloženi vodni resursi i ekosistemi mogu dodatno pogoršati ovo stanje. Sprovođenje bilo koje politike u oblasti smanjenja siromaštva, održivog razvoja i zaštite biodiverziteta nemoguće je bez aktivnog učešća i vođstva od strane lokalnih vlasti u saradnji sa njihovim strateškim partnerima (kao što su nacionalne vlasti, civilni sektor i poslovna zajednica). Stoga je upravljanje vodama na lokalnom nivou osnovni element dobrog upravljanja vodama u celini.

Imajući navedeno u vidu, kao osnovni metodološki postupak za unapređenje bezbednosti vode u zemljama Bliskog istoka i severne Afrike (MENA) odabrana je izrada Lokalnih planova bezbednosti vode (Local Water Security Action Plans - LWSAP).

Lokalni planovi bezbednosti vode odražavaju prioritete nacionalnih, regionalnih i međunarodnih politika, ali i rešavaju pitanja vodne bezbednosti na lokalnom nivou kao preduslov za dobrobit lokalnog stanovništva. Razvoj LWSAP-a takođe osigurava primenu integrisanog pristupa upravljanju vodama kao sredstva za unapređenje sigurnosti vode, kako bi se prikazali direktni i opipljivi rezultati podrške dijalogu o vodama i izgradnji kapaciteta. Sa druge strane, implementacija mera za postizanje vodne bezbednosti na lokalnom nivou može imati značajne šire regionalne uticaje, naročito za korisnike koji se nalaze nizvodno.

U okviru projekta WaterSUM razvijeni su inovativni pristupi i alati, koji su testirani kroz pilot-projekte na osam različitih urbanih i periurbanih lokacija u Jordanu i Tunisu (Džeraš, Karak, Adžlun i Salt u Jordanu, te Matmata, Nefza, Bir Mčerga i Sidi Ali Ben Oun u Tunisu). Lokalni proces akcionog planiranja vodne bezbednosti dizajniran je tako da obuhvata dva međusobno povezana koraka: procenu trenutnog stanja vodne bezbednosti i razvoj akcionog plana ili plana upravljanja. Metodologija za planiranje, opisana detaljno u priručniku za planiranje (8), bazirana je na elementima preuzetim iz dve metodologije za procenu: Water Security Status Indicators (WSSI); i Canadian Water Sustainability Index (CWSI). Autori su razvili originalnu metodologiju koja obuhvata sedam međusobno povezanih aktivnosti, uključujući analizu zainteresovanih strana, procenu javnog mnjenja, lokalnu procenu bezbednosti vode i analizu problema i prioriteta (slika 3). Svaka od sedam aktivnosti sadrži dva ili više koraka, što čini ukupno 20 koraka u procesu planiranja. 


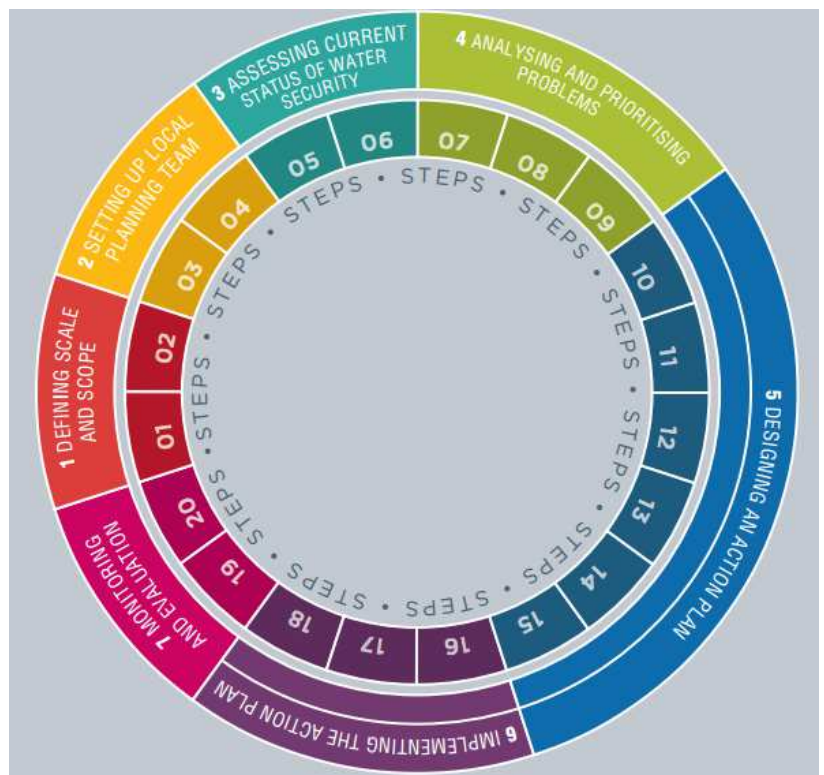

Slika 3. Shematski prikaz procesa izrade lokalnih planova bezbednosti vode (8)

Lokalni procesi akcionog planiranja vodne bezbednosti, bazirani na metodologiji opisanoj u priručniku, započeti su u osam polaznih lokalnih zajednica početkom 2016. godine (9). Maja 2017. godine proces planiranja je završen i svih osam lokalnih zajednica sačinilo je nacrte akcionih planova, koji se mogu preuzeti na: http://watersum.rec.org/index.php?page=library-2.

\section{Zaključak}

Iako je još rano za konačnu evaluaciju pilot-procesa, neka zapažanja se nameću. Kao prvo, nema dileme da se planiranje vodne bezbednosti na lokalnom nivou, bazirano na metodologiji koja je ponuđena, može smatrati neophodnim procesom za lokalne zajednice u regionu, posebno za one koje su bile uključene u projekat. $\mathrm{U}$ ovom momentu neophodnost korišćenja metodologije za planiranje akcija u oblasti vodne bezbednosti na lokalnom nivou ne dovodi se u pitanje, premda se može raspravljati o detaljima metodološkog pristupa, uključujući i njegovo poboljšanje.

Kada se govori o samom procesu planiranja, postoji generalni problem nedostatka pouzdanih podataka. Sâm proces planiranja se pokazao ekstremno dugotrajnim, zbog nedostatka pouzdanih podataka i veština za njihovo prikupljanje i analizu, što se pre svega odnosi na analizu zatečenog stanja. Zbog toga je u nekim lokalnim zajednicama dolazilo do kašnjenja, a u nekim slučajevima rezultati planiranja nisu bili zadovoljavajući. 
Praćenje razvoja na lokalnom nivou i monitoring razvojnog procesa sve više se smatra osnovom za uspeh bilo koje razvojne inicijative. Međutim, i ovde najveći problem leži u nedostatku pouzdanih i relevantnih podataka i, još više, sistematskog upravljanja, obrade i obnavljanja ovih podataka.

Uspešnost planiranja na lokalnom nivou bila je u direktnoj korelaciji sa administrativnim nivoom i unutrašnjim kapacitetima lokalne vlasti da uključi zainteresovane strane u proces planiranja. Lokalne vlasti u regionu razlikuju se i imaju različite nivoe znanja i ljudskih resursa. Međutim, uloga facilitatora pokazala se kao veoma važna u svakoj lokalnoj zajednici, jer su oni pokretali proces i osiguravali da on bude uspešan i da se rokovi poštuju.

Proces planiranja se zasnivao na klasičnoj metodologiji participativnog planiranja. Međutim, interesovanje javnosti za učešće u planiranju vodne bezbednosti još je malo, uprkos skorašnjim povoljnim iskustvima.

Zajedničko razumevanje potrebe za strateškim pristupom u planiranju vodne bezbednosti i sama metodologija koja se koristila samo su u manjoj meri predstavljali administrativni problem, pre svega u ranoj fazi procesa planiranja. Sa druge strane, najveći izazov je bio da se proces tako dizajnira da lokalnoj zajednici bude vidljiv i atraktivan, a posebno da se održe motivacija za rad i produktivne „tenzije“ unutar radnih grupa tokom dugotrajnog procesa, kakav je po prirodi proces formulisanja strategije i njene implementacije.

\section{Izjava zahvalnosti}

Ovaj rad je napisan na osnovu istraživanja urađenih u okviru projekta "WaterSUM - Sustainable Use of Transboundary Water Resources and Water Security Management" Regionalnog centra za životnu sredinu (Regional Environmental Center REC) iz Budimpešte, finansiranog od strane Švedske agencije za međunarodnu razvojnu saradnju (SIDA).

\section{Literatura}

1. GWP (2000). Towards Water Security: A Framework for Action. Global Water Partnership. Stockholm and London.

2. WWC (2000). A Water Secure World - Vision for Water, Life and the Environment. Commission Report.

3. Grey, D. and C. Sadoff (2007). "Sink or Swim? Water security for growth and development." Water Policy 9 (2007): 545-557.

4. UN-Water (2013). Analytical Brief on Water Security and the Global Agenda, http://i.unu.edu/media/unu.edu/publication/34287/UNWater_watersecurity_analytic albrief.pdf

5. van Beek, E., Arriens W.L. (2014). Water Security: Putting the Concept into Practice. Global Water Partnership Background Papers No 20.

6. WaterAid (2012). Water security framework. London: WaterAid. 
7. Milutinović, S., R. Laušević, J. Petersen-Perlman, M. Bartula, A. Solujić (2016). Local Water Security Assessment for Improved Water Management in Selected Countries in the Middle East and North Africa (MENA) Region. Szentendre, Hungary: Regional Environmental Center.

8. Laušević, R., S. Milutinović, J. Petersen-Perlman, M. Reed, A. Graves, M. Bartula, S. Sušić, A. Popović (2016). Local Water Security Action Planning Manual. Szentendre, Hungary: Regional Environmental Center.

9. Laušević, R. V. Vassilev, A. Kis, F. Abdulla, S. Milutinović (2016). Water, Growth and Stability. Background document for the REC's World Café 2016 at WWW2016. Szentendre, Hungary: Regional Environmental Center Hungary.

\section{PLANNING LOCAL WATER SECURITY IN A CHANGING CLIMATE - MENA CASE STUDY}

\section{Summary}

Water security is much more than having enough water; it implies all issues related to the 'too much water', 'too little water', and 'too dirty water' aspects. Today many people in urban areas are facing those issues, solvable to a certain extent by good water management in cities. However, water security is much more than good water management: it is about mitigating water-related risks, such as floods and droughts, addressing conflicts that arise from disputes over shared water resources, and resolving tensions among the various stakeholders who compete for a limited resource (van Beek and Arriens, 2014).

In 2009, the World Economic Forum (WEF) prioritised water security as a global risk, stating that "water security is the gossamer that links together the web of food, energy, climate, economic growth, and human security challenges that the world economy faces over the next decades' (WEF, 2009). As defined in the Global Water Partnership declaration, water security, at any level from the household to the global, means that every person has access to enough safe water at affordable cost to lead a clean, healthy, and productive life, while ensuring that the natural environment is protected and enhanced. Water security involves the sustainable use and protection of water systems, the protection against water related hazards (floods and droughts), the sustainable development of water resources and the safeguarding of (access to) water functions and services for humans and the environment.

Water security arises at two interconnected levels: local/national and regional/international. At the local/national level, the security of access to the resource is the crucial problem. At the regional/international level, the primary concern is about potential international conflicts and tensions resulting from traditional national security approaches with a focus on hydro $\square$ sovereignty. In both cases the good water governance is pivotal in achieving water security. However, it is increasingly recognized today that problems related to water security can be successfully addressed at local community level, especially the protection 
against water related hazards associated with climate changes, local availability of water resources and water protection.

This paper is about 'WaterSUM - Sustainable Use of Transboundary Water Resources and Water Security Management', a learning and development project that aimed to improve water security at the local level, dominantly in cities and towns in two MENA countries: Jordan and Tunisia. The project, led by the Regional Environmental Centre - REC and funded by the Swedish International Development Cooperation Agency (SIDA), ran from 2014 to 2017 in Jordan, Tunisia, Egypt and Morocco, where water management and security are high priorities. The overall objective of the project was to promote and enhance sustainable water resources management and to promote a comprehensive and integrated approach to water security and ecosystem services for sustainable development in beneficiary countries in the MENA region in order to help halt the downward spiral of poverty, biodiversity loss and environmental degradation.

Local Water Security Action Planning was given a pivotal place in the WaterSUM Component 2, "Water and Security" (WaSe). Why local water security? At the local level water insecurity, either water scarcity or low quality of water, may lead to political instability or conflict, often exacerbated by attempts at profiteering through private uncontrolled sales of water. Threats to water resources or ecosystems can further aggravate these conditions. Implementation of any policy in the field of poverty reduction, sustainable development and the conservation of biodiversity is impossible without the active participation and ownership of local communities and local governments with the help of their strategic partners (such as national authorities, CSOs and businesses). Therefore, local water governance is essential element of overall good water governance.

WaterSUM developed its innovative approaches and tools and tested them through pilot projects in the eight different urban and peri-urban locations in Jordan and Tunisia (Jerash, Karak, Ajloun and Salt in Jordan; Matmata, Nefza, BirMcherga and Sidi Ali Ben Aoun in Tunisia). Local water security action planning process was designed to comprise two interrelated steps: an assessment of the current status of water security; and the development of a management or action plan. The planning methodology, described in detail in the planning manual (http://documents.rec.org/publications/LWSAP_Manual_April2016.pdf), applied elements from two assessment methodologies: Water Security Status Indicators (WSSI); and the Canadian Water Sustainability Index (CWSI). The manual is a step-by-step guidebook for practitioners who are developing local water security action plans (LWSAPs) in local communities. The authors compiled an original methodology comprising seven interrelated activities covering stakeholder analysis, public opinion assessment, local water security assessment, and problem analysis and prioritization. Each of the seven activities comprises two or more steps, making a total of 20 steps in the LWSAP process.

Local water security action planning process in eight local governments in Jordan and Tunisia, based on the methodology drafted in the Manual, was initiated in early 2016. Currently, the process is approaching the final phase and majority of pilot local administrations have developed a draft action plan. Although it is still early to perform the final evaluation of pilot process, some observations can be made. 
Firstly, there is no doubt that local water security planning, based on the methodology provided, is considered indispensable process for local communities in the region, particularly the ones included in the project. Currently the necessity of using such methodology for action planning at the local level is not to be questioned, the discussion is about details of methodological approach, including their improvements.

When it comes to planning process itself, there is a general problem with a lack of reliable data. Planning processes itself emerges as extremely time-consuming, particularly situation analysis, due to the lack of reliable information and skills for data acquisition and analysis. As a result, some strategic planning exercises have faced the shortage of time, and sometimes the results of planning process have not been successful.

Measuring development at a local level and monitoring development progress is increasingly being viewed as fundamental to any successful development initiative. However, a major problem is the lack of reliable and pertinent data and furthermore - its systematic management, processing and update.

The success of local planning processes was in direct correlation with the administrative level and internal capacity of local government to engage stakeholders for entire process. Local communities in the region are different, with different expertise and human resources. However, the role of facilitators was very important in every community, they had to move things forward and make sure that a plan was produced and that deadlines were met.

Planning exercises were based on classical participatory planning methodology. Nonetheless, public interest in participating in local water security planning is still limited, despite recent positive examples in this regard.

Common understanding of the necessity of strategic approach and methodology provided has an effect on only limited and sporadic administrative problems during the planning processes, particularly in the early phase. However, the main challenge was to design the process so as to be visible and attractive for the community, and, in particular, to maintain the motivation for work and 'tensions' inside working groups during the long-term process as the strategy formulation and implementation should be.

Keywords: water security, action planning, local communities, MENA countries 